\title{
Genetic heterogeneity of Pseudomonas aeruginosa clinical isolates revealed by esterase electrophoretic polymorphism and restriction fragment length polymorphism of the ribosomal RNA gene region
}

\author{
B. PICARD, E. DENAMUR*, A. BARAKAT, J. ELION* and P. GOULLET†
}

Laboratoire de Microbiologie, Faculté de Médicine Xavier Bichat, 16 rue de Henri Huchard, 75018 Paris and * Laboratoire de Biochimie Génétique and INSERM U 120, Hôpital Robert Debré, 48 Boulevard Serurier, 75019 Paris, France

\begin{abstract}
Summary. The intra-species differentiation of Pseudomonas aeruginosa was analysed by comparing the polymorphism of esterases by conventional polyacrylamide-agarose gel electrophoresis, the physicochemical properties of the variants of the major esterase $\mathrm{P}_{3}$ and the restriction fragment length polymorphism of ribosomal RNA gene regions (ribotyping) to O-serotyping for several panels of strains selected from among a series of 257 clinical isolates and two references strains, (ATCC nos. 10145 and 27853). The electrophoretic variation of four main kinds of esterase $\left(\mathrm{P}_{1}-\mathrm{P}_{4}\right)$ and 11 additional esterases distinguished by their spectra of hydrolytic activity with synthetic substrates and by their sensitivity to di-isopropylfluorophosphate, allowed the discrimination of 67 zymotypes. Thirty-two esterase $\mathrm{P}_{3}$ variants were characterised by their $\mathrm{pI}$, electrophoretic mobilities and titration curve analyses. They were distributed into two groups which, by these molecular criteria, seem to be distantly related. Combination of the patterns resulting from HindIII, EcoRI and BclI restriction endonuclease digestions allowed the discrimination of 33 ribotypes among 134 strains. The strains exhibiting esterase $P_{3}$ variants of group 2 presented a distinct ribotype and belonged to serotype $\mathrm{O} 12$. They could constitute a distinct group within the species. For the majority of the strains, the absence of correlation between zymotype, ribotype and serotype argues for a high level of heterogeneity within $P$. aeruginos $a$ and indicates that the parallel use of the first two methods represent a potential tool for epidemiological study.
\end{abstract}

\section{Introduction}

The epidemiological fingerprinting of many pathogenic bacterial species is studied routinely by conventional phenotypic tests. The conventional characters do not provide an adequate basis with which to evaluate the heterogeneity of the species and the genetic distance between strains. This distance can be estimated by enzyme electrophoretic polymorphism ${ }^{1,2}$ -however, it has been recognised that the use of a single electrophoretic technique reflects incompletely the allelic variation of enzymes. To improve the detection of cryptic enzyme variations, previously we have used polyacrylamide agarose gel electrophoresis and thin-layer iso-electric focusing (IEF) in parallel runs, and proposed a two-dimensional electrophoretic profile (2-DEP). ${ }^{3}$ We have also evaluated the mol-

Received 1 July 1993; accepted 4 Oct. 1993.

† Present address and address for correspondence: Service de Microbiologie, Hôpital Beaujon, 100 Boulevard du Général Leclerc, 92110 Clichy, France. ecular relationship between the enzyme electrophoretic variants by comparative titration curve. ${ }^{4-6} \mathrm{On}$ the other hand, it has been established that the parallel use of molecular typing systems studying different classes of genetic variation improves the intra-species differentiation of bacteria. The analysis of DNA restriction fragment length polymorphism (RFLP) is very sensitive to small changes in DNA organisation. ${ }^{7}$ The study of variations in the ribosomal DNA (rDNA) gene regions (ribotyping) ${ }^{8-10}$ has the advantage that it examines several sequences of the genome that encode a function distinct from that of enzymes. Consequently, the combining of ribotyping and enzyme electrophoresis has provided useful information on the genetic relatedness of strains within a bacterial species. ${ }^{11-13}$

During the last 20 years, the prevalence of Pseudomonas aeruginosa, a major opportunist pathogen, has increased in nosocomial infections. Precise epidemiological analyses are necessary for the prevention and control of these infections. The main epidemiological markers remain phenotypic, including API 20NE 
profile, O serotype, pyocin type, phage type, lysogenic state and antibiotic susceptibility. In earlier reports we proposed a typing method based upon the variation of four esterases, $\mathrm{P}_{1}-\mathrm{P}_{4}$, characterised by polyacrylamide agarose gel electrophoresis ${ }^{14}$ and used this method in comparison with RFLP or the rDNA gene region for epidemiological analysis of strains obtained from cystic fibrosis $(\mathrm{CF})$ patients originating from a single hospital. ${ }^{15}$ The present work utilised a large panel of $257 P$. aeruginosa clinical isolates obtained in various hospitals and from several sites of infection (and from $\mathrm{CF}$ and non-CF patients) and compared the results obtained by three molecular typing methods: esterase electrophoresis in polyacrylamide agarose gel; IEF of the electrophoretic variants of the main esterase $\mathrm{P}_{3}$ with the evaluation of the molecular relationships between these variants by titration curves; and RFLP of rDNA.

\section{Materials and methods}

\section{Bacterial strains}

A total of 257 clinical $P$. aeruginosa strains was studied. They were collected from patients in nine hospitals located in eight cities in France (table I). All were isolated from pathological samples (urine, stool, blood, trachea or sputum) and were collected between 1984 and 1990. Fifty-six strains were from CF patients. Isolates were identified as $P$. aeruginosa based upon typical morphology, positive oxidase reaction, ability to produce pigments, growth at $42^{\circ} \mathrm{C}$ and biochemical tests (API-20 NE system; API, les Balmes, France). O serotyping was performed with O-antisera (Diagnostic Pasteur, Marne la Coquette, France). The strains belonged to 16 of the 17 serogroups of the international serotyping scheme. ${ }^{16}$ Two reference strains also studied were the type strain of the species, ATCC 10145 and strain ATCC 27853.

\section{Esterase electrophoretic polymorphism}

Bacteria were grown for $18 \mathrm{~h}$ at $37^{\circ} \mathrm{C}$ in broth ${ }^{17}$ with constant shaking and then harvested by centrifugation. Bacterial pellets were washed with $60 \mathrm{~mm}$ Trisglycine buffer, $\mathrm{pH} 8.7$, resuspended in the same buffer and disrupted by sonication for $18 \mathrm{~min}$ at $4{ }^{\circ} \mathrm{C}$. Crude extract supernates containing $40-60 \mathrm{mg}$ of protein $/ \mathrm{ml}$, were stored at $-20^{\circ} \mathrm{C}$ until used. ${ }^{18}$

\section{Conventional electrophoresis}

Horizontal slab gel electrophoresis was performed according to the method of Uriel ${ }^{19}$ in a composite polyacrylamide-agarose gel $(7 \%$ and $1.4 \%$, respectively) in a discontinuous Tris-glycine buffer, $\mathrm{pH} 8.7$, at constant voltage $(7 \mathrm{~V} / \mathrm{cm})$ until the bromophenol blue marker had run $13 \mathrm{~cm}$. The relative mobility $\left(M_{F}\right.$ value) is the distance moved by the esterase band as a percentage of the distance moved by the dye front. $\mathrm{M}_{\mathrm{F}}$ values were compared by running bacterial extracts in contiguous tracks on the same gel. ${ }^{3}$

\section{Iso-electric focusing}

Thin-layer iso-electric focusing in polyacrylamide gels $(\mathrm{T}=5 \%, \mathrm{C}=3 \%)^{20}$ was performed at $4^{\circ} \mathrm{C}$ with carrier ampholytes of $\mathrm{pH}$ range 4-6.5 (Pharmalyte; Pharmacia, Uppsala, Sweden) according to the manufacturer's instructions. Experiments were run at a constant power of $25 \mathrm{~W}$ for $2 \mathrm{~h}$ at $4^{\circ} \mathrm{C}$. Under these conditions the samples reached their equilibrium position (pI position) after $90 \mathrm{~min}$ and a further condensation of the zone occurred after $30 \mathrm{~min}$. The $\mathrm{pH}$ gradient was measured systematically for each gel after the elution of the carrier ampholytes from a zone where no sample was applied. Iso-electric points (pI) of esterases were determined by interpolation from this curve.

\section{Titration curves by combined iso-electric focusing- electrophoresis}

The technique employed was that described by Righetti et al.$^{4}$ Briefly, as a first step, a $\mathrm{pH}$ gradient was formed extending from 3.5 to 10 , the sample was then applied in a groove running all along the gradient and electrophoresis was performed perpendicular to this gradient. Sigmoidal pH-mobility curves approximating to titration curves were revealed by specific staining procedures for the esterases with $\alpha$-naphthyl acetate as a substrate, as described below.

\section{Esterase staining}

Esterases were stained on the gel ${ }^{21,22}$ with the following specific substrates: $\alpha$-naphthyl acetate, $\beta$ naphthyl acetate, $\alpha$-naphthyl propionate, $\beta$-naphthyl propionate, $\alpha$-naphthyl butyrate, $\beta$-naphthyl butyrate and indoxyl acetate (Sigma). The sensitivity of esterases to di-isopropylfluorophosphate (DFP) $\left(10^{-3} \mathrm{M}\right)$ was also tested.

\section{RFLP of $r D N A$ regions}

Bacterial DNA was prepared as described previously. ${ }^{9}$ DNA ( $(5 \mu \mathrm{g})$ was digested with HaeIII, HinfI, TaqI, HindIII, EcoRI, and $B c /$ I restriction endonucleases (Boehringer Mannheim, Germany) according to the manufacturer's specifications and analysed by electrophoresis on submarine agarose $0.8 \%$ gels containing ethidium bromide. DNA fragment sizemarker Raoul I (Appligene, Strasbourg, France) was used. Separated DNA restriction fragments were transferred to a nylon membrane (Gene Screen Plus, New England Nuclear Products, Boston, MA, USA) by the method of Southern. ${ }^{23}$ Ribosomal $16+23 \mathrm{~S}$ RNA from Escherichia coli (Boehringer) was labelled by random oligopriming with a mixture of hexanucleo- 
Table I. Geographical location of the 257 P. aeruginosa clinical isolates

\begin{tabular}{llc}
\hline \multicolumn{1}{c}{ Town } & \multicolumn{1}{c}{ Hospital } & Number of strain \\
\hline Paris & Beaujon hospital & 76 \\
Paris & Robert Debré hospital & 48 \\
Compiègne & General hospital & 9 \\
Amiens & Regional hospital & 5 \\
Abbeville & General hospital & 5 \\
Rennes & Pontchaillon hospital & 22 \\
Lyon & E. Herriot hospital & 44 \\
Marseille & Salvator hospital & 29 \\
Tours & Bretonneau hospital & 19 \\
& & \\
\hline
\end{tabular}

tides (Pharmacia) and cloned M-MLV reverse transcriptase (Bethesda Research Laboratory, Gaithersburg, MD, USA) in the presence of $\left[{ }^{32} \mathrm{P}\right] \mathrm{dCTP}\left(2^{\prime}\right.$ deoxycytidine-5'-triphosphate, $800 \mathrm{Ci} / \mathrm{mmol}$; Amersham). Hybridisation, washing and autoradiographic procedures were as described previously."

\section{Reproducibility of the results}

Electrophoretic relationships between the strains were established by numerous replicate runs comparing enzyme bands side by side on the same gel. The reproducibility of the results was confirmed in several ways. For pI values, all the samples coalesced as a single line after IEF when they were loaded at different positions on the gel, and samples remained in the same line with no additional bands being observed when IEF was continued for an additional 30 -min period to condense the focused region. All values of both $\mathrm{pI}$ and $\mathbf{M}_{\mathrm{F}}$ were tested by comparing each new strain with reference strains in all electrophoretic runs; 4-12 extracts of the same strain were tested and had the same pI in IEF and the same electrophoretic re- lationship in CE. Reproducibility of the rDNA RFLP results was established by multiple runs comparing separated DNA fragments side by side on the same gel.

\section{Results}

\section{Esterase electrophoretic polymorphism}

Conventional electrophoresis. Among the $259 P$. aeruginosa strains, four main kinds of esterase bands were identified by their activity toward the synthetic substrates and by their sensitivity or resistance to DFP (table II). They were numbered $\mathrm{P}_{1}-\mathrm{P}_{4}$ in order of decreasing mobility toward the anode. Eleven additional esterase bands (AE) were observed which were present in some strains only.

Each kind of esterase showed a number of electrophoretic variants (table III). The genetic diversity coefficients $^{24}$ were $0 \cdot 13,0 \cdot 72,0.78$ and 0.02 for esterases $\mathrm{P}_{1}, \mathrm{P}_{2}, \mathrm{P}_{3}$ and $\mathrm{P}_{4}$, respectively. The polymorphic esterase $P_{3}$ showed eight mobility variants corresponding to electrophoretic steps from $\mathrm{M}_{\mathrm{F}} \approx 44$ to $\mathrm{M}_{\mathrm{F}} \approx 58$. Together, the combination of the electrophoretic variants of the main esterases and the presence of additional bands allowed the identification of 67 zymotypes among the $259 P$. aeruginosa strains (table III). Some zymotypes were observed more frequently than others. Zymotype 29 was the most common and was found in 62 strains. Zymotypes 56, 8, 44, 51 and 34 were observed in $32,22,19,14$ and 13 strains respectively. Other zymotypes were observed in nine strains or less.

Iso-electric focusing. A panel of 74 strains was selected on the basis of the data obtained with the esterase electrophoretic typing, i.e., one or two strains from each zymotype, to study the esterase $\mathrm{P}_{3}$ electrophoretic polymorphism further by iso-electric focusing

Table II. Characteristics of esterase bands of $P$. aeruginosa

\begin{tabular}{|c|c|c|c|c|c|c|c|c|}
\hline \multirow{2}{*}{ Esterase } & \multicolumn{7}{|c|}{ Substrates hydrolysed* } & \multirow{2}{*}{$\begin{array}{c}\text { DFP } \\
\left(10^{-3} \mathrm{M}\right)\end{array}$} \\
\hline & $\alpha \mathrm{NA}$ & $\alpha N P$ & $\alpha \mathrm{NB}$ & IA & $\beta \mathrm{NA}$ & $\beta \mathrm{NP}$ & $\beta \mathrm{NB}$ & \\
\hline$P_{1}$ & + & + & - & - & ++ & ++ & + & $\mathbf{R}$ \\
\hline$P_{2}$ & - & - & - & - & + & + & + & $S$ \\
\hline $\mathbf{P}_{3}$ & +++ & +++ & ++ & ++ & ++ & ++ & + & $\mathbf{S}$ \\
\hline$P_{4}$ & - & - & - & - & - & + & + & $\mathbf{R}$ \\
\hline $\mathrm{AE} 1$ & + & + & - & + & + & + & - & $\mathbf{R}$ \\
\hline $\mathrm{AE} 2$ & + & + & - & - & + & + & - & $\mathrm{S}$ \\
\hline AE 3 & + & + & - & - & - & - & - & $\mathbf{S}$ \\
\hline $\mathrm{AE} 4$ & - & + & + & + & + & + & + & $\mathbf{R}$ \\
\hline AE 5 & + & + & - & + & ++ & ++ & ++ & $\mathbf{S}$ \\
\hline AE 6 & - & - & - & + & - & - & - & $\mathbf{R}$ \\
\hline $\mathrm{AE} 7$ & + & + & + & - & + & + & + & $\mathbf{S}$ \\
\hline AE 8 & + & - & + & - & - & - & - & $\mathbf{R}$ \\
\hline AE 9 & + & - & - & - & - & - & - & $\mathbf{R}$ \\
\hline $\mathrm{AE} 10$ & - & - & - & - & + & + & + & $\mathbf{R}$ \\
\hline $\mathrm{AE} 11$ & - & - & - & - & - & - & + & $\mathrm{S}$ \\
\hline
\end{tabular}

$\alpha$ NA, $\alpha$-naphthyl acetate: $\alpha \mathrm{NP}, \alpha$-naphthyl propionate; $\alpha \mathrm{NB}, \alpha$-naphthyl butyrate; IA, indoxyl acetate; $\beta \mathrm{NA}, \beta$-naphthyl acetate; $\beta \mathrm{NP}, \beta$-naphthyl propionate; $\beta \mathrm{NB}, \beta$-naphthyl butyrate; $\mathrm{R}$, resistant; $\mathrm{S}$, sensitive; $\mathrm{AE}$, additional esterase.

* Relative intensity of staining: $+++>++>+$ undetected - . 
Table III. Distribution of the $259 P$. aeruginosa strains studied among the 67 zymotypes resulting from esterase electrophoresis

\begin{tabular}{|c|c|c|c|c|c|c|c|}
\hline Zymotype & $\begin{array}{c}\mathrm{P}_{1} \\
\left(\mathrm{M}_{\mathrm{F}}\right)\end{array}$ & $\begin{array}{c}\mathrm{P}_{2} \\
\left(\mathrm{M}_{\mathrm{F}}\right)\end{array}$ & $\underset{\left(\mathrm{M}_{\mathrm{F}}\right)}{\mathrm{P}_{3}}$ & $\begin{array}{c}\mathrm{P}_{4} \\
\left(\mathrm{M}_{\mathrm{F}}\right)\end{array}$ & $\underset{\left(\mathrm{M}_{\mathrm{F}}\right)}{\mathrm{AE}}$ & $\begin{array}{l}\text { Number of } \\
\text { strains }\end{array}$ & Serotype \\
\hline 1 & & & 44 & 26 & \multirow[t]{8}{*}{$60(4)$} & 1 & 13 \\
\hline 2 & & 63 & 44 & 26 & & 1 & 12 \\
\hline 3 & & 65 & 44 & 26 & & 1 & 12 \\
\hline 4 & & 66 & 44 & 26 & & 2 & 12 \\
\hline 5 & 63 & & 44 & 26 & & 1 & 12 \\
\hline 6 & 66 & 52 & 46 & 26 & & 1 & 9 \\
\hline 7 & 65 & 55 & 46 & 26 & & 1 & 11 \\
\hline 8 & 66 & 55 & 46 & 26 & & 22 & $1,7,8,10,11,15$ \\
\hline 9 & 66 & 55 & 46 & 26 & \multirow{2}{*}{$32(6)$} & 1 & $\mathrm{U}$ \\
\hline 10 & 66 & 55 & 46 & 30 & & 1 & 6 \\
\hline 11 & & 57 & 46 & 26 & \multirow{3}{*}{$55(5)$} & 1 & 11 \\
\hline 12 & 66 & 60 & 46 & 26 & & 2 & 8,10 \\
\hline 13 & 66 & 60 & 46 & 30 & & 1 & U \\
\hline 14 & 66 & & 46 & 26 & \multirow{12}{*}{$\begin{array}{l}60(4) \\
55(5) \\
55(5)\end{array}$} & 2 & $4, U$ \\
\hline 15 & 66 & & 46 & 26 & & 1 & 11 \\
\hline 16 & 66 & & 46 & 30 & & 1 & 3 \\
\hline 17 & 66 & 55 & 48 & 26 & & 3 & $9,10, U$ \\
\hline 18 & 66 & 56 & 48 & 26 & & 9 & $1,4,5,11, \mathrm{U}$ \\
\hline 19 & 66 & 57 & 48 & 26 & & 1 & 10 \\
\hline 20 & 65 & 60 & 48 & 26 & & 1 & $\mathrm{U}$ \\
\hline 21 & 66 & & 50 & 26 & & 6 & $3,4,9$ \\
\hline 22 & 63 & 54 & 50 & 26 & & 1 & 5 \\
\hline 23 & 66 & 54 & 50 & 26 & & 2 & 1 \\
\hline 24 & 66 & & 50 & $26 / 55$ & & 1 & 1 \\
\hline 25 & 66 & & 50 & $26 / 60$ & & 1 & $\mathrm{U}$ \\
\hline 26 & 66 & & 50 & 26 & \multirow{4}{*}{$\begin{array}{l}52(9) \\
54(9) \\
56(9)\end{array}$} & 1 & 3 \\
\hline 27 & 66 & & 50 & 26 & & 1 & 6 \\
\hline 28 & 66 & & 50 & 26 & & 1 & $\mathrm{U}$ \\
\hline 29 & 66 & & 52 & 26 & & 62 & $1,3,6,11,12,13$ \\
\hline 30 & 66 & 35 & 52 & 26 & \multirow{5}{*}{$35(1)$} & 2 & 12 \\
\hline 31 & 66 & 48 & 52 & 26 & & 5 & 5,6 \\
\hline 32 & 66 & 48 & 52 & 26 & & 1 & $\mathrm{U}$ \\
\hline 33 & 66 & 55 & 52 & 26 & & 1 & $\mathrm{U}$ \\
\hline 34 & 66 & 56 & 52 & 26 & & 13 & $1,3,6,9,12,16$ \\
\hline 35 & 66 & 56 & 52 & 26 & $35(1)$ & 1 & 10 \\
\hline 36 & 66 & 56 & 52 & 26 & $35(2)$ & 2 & 5,16 \\
\hline 37 & 66 & 56 & 52 & 26 & $40(2)$ & 1 & $\mathrm{U}$ \\
\hline 38 & 66 & 56 & 52 & 26 & \multirow[t]{3}{*}{$10(8)$} & 1 & 4 \\
\hline 39 & 70 & 56 & 52 & $26 / 60$ & & 1 & 1 \\
\hline 40 & & 56 & 52 & 26 & & 3 & $1,3,4$ \\
\hline 41 & 66 & 57 & 52 & 26 & \multirow{4}{*}{$70(7)$} & 1 & 9 \\
\hline 42 & 63 & & 55 & 26 & & 1 & 11 \\
\hline 43 & 66 & 47 & 55 & 26 & & 1 & 16 \\
\hline 44 & 66 & & 55 & 26 & & 19 & $1,3,6,10$, \\
\hline 45 & $66 / 42$ & & 55 & 26 & & 1 & $\mathrm{U}$ \\
\hline 46 & & 35 & 55 & 26 & & 1 & 7 \\
\hline 47 & & 56 & 55 & 26 & & 1 & 16 \\
\hline 48 & 66 & 50 & 55 & 26 & & 1 & 4 \\
\hline 49 & 66 & 56 & 55 & 26 & & 2 & 1,3 \\
\hline 50 & 66 & 60 & 55 & 26 & & 2 & 2,6 \\
\hline 51 & 66 & & 56 & 26 & & 14 & $3,6,11$, \\
\hline 52 & 66 & & 56 & 26 & $32(1)$ & 1 & 6 \\
\hline 53 & 66 & & 56 & 26 & 35 & 1 & $\mathrm{U}$ \\
\hline 54 & 66 & & 56 & $26 / 52$ & & 1 & 15 \\
\hline 55 & 66 & 50 & 56 & 26 & & 3 & 1 \\
\hline 56 & 66 & 52 & 56 & 26 & & 32 & $1,2,3,6$, \\
\hline 57 & 66 & 52 & 56 & 26 & 35 & 1 & $\mathrm{U}$ \\
\hline 58 & 66 & 52 & 56 & 26 & $35(2)$ & 1 & 6 \\
\hline 59 & & & 56 & 26 & & 1 & $\mathbf{U}$ \\
\hline 60 & 66 & 53 & 56 & 26 & & 1 & 1 \\
\hline 61 & 66 & 60 & 56 & 26 & & 4 & 11 \\
\hline 62 & 66 & 52 & 58 & 26 & $35(1)$ & 3 & $1,6,16$ \\
\hline 63 & 66 & 60 & 58 & 26 & & 1 & 11 \\
\hline 64 & 66 & & & 26 & $48(3)$ & 1 & 15 \\
\hline 65 & 66 & 55 & & 26 & & 1 & 1 \\
\hline 66 & 66 & & & 26 & $52(5)$ & 1 & 6 \\
\hline 67 & 66 & & & 26 & $\begin{array}{r}56(10) \\
+52(11)\end{array}$ & 1 & $U$ \\
\hline
\end{tabular}

$\mathrm{AE}$, additional esterase - the $\mathrm{AE}$ are numbered (in brackets) as in table II; U, unserotypable strain.

and titration curve analysis. On iso-electric focusing, 13 allelic esterase $P_{3}$ variants were detected with isoelectric points varying from $\mathrm{pH} 4.9$ to $\mathrm{pH} 5 \cdot 5$.
Two-dimensional electrophoretic profile. By plotting mobility values versus $\mathrm{pI}$ for all the esterase $\mathrm{P}_{3}$ variants, a two-dimensional profile $(2-\mathrm{DEP})^{3,6}$ was obtained 


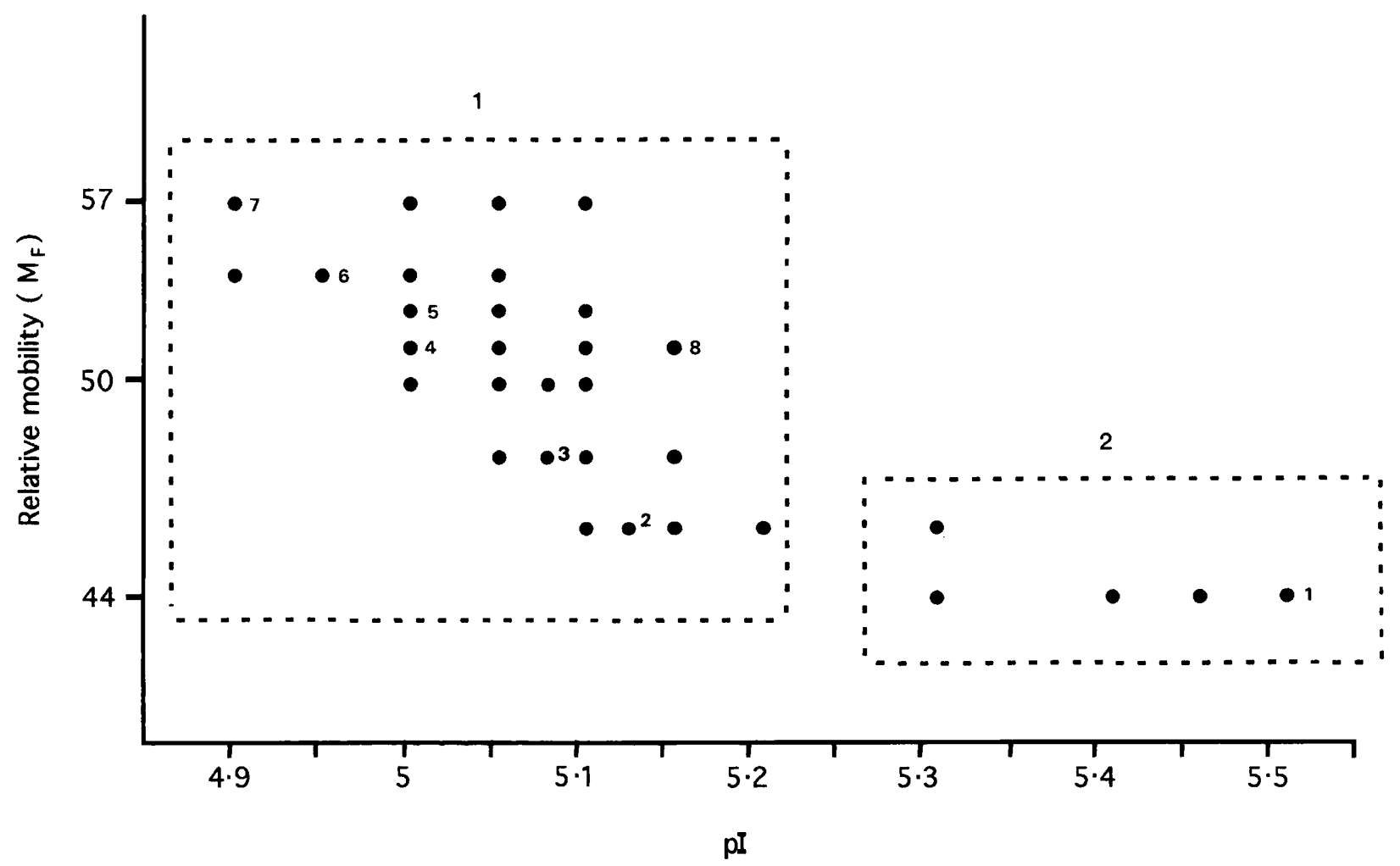

Fig. 1. Two-dimensional electrophoretic profile of the 32 esterase $P_{3}$ electromorphs produced by the $74 P$. aeruginosa strains. The groups of electromorph 1 and 2 are indicated (see results). The electromorphs used for the titration curve analyses are labeled 1-8.

(fig. 1). This representation allowed discrimination of 32 variants or electromorphs. These variants may be classified into two distinct electrophoretic groups. Group 1 was defined by mobilities ranging from $\mathrm{M}_{\mathrm{F}} \approx 46$ to $\mathrm{M}_{\mathrm{F}} \approx 57$ and by $\mathrm{pI}$ from 4.9 to $5 \cdot 2$ and encompassed 27 variants. Group 2 was defined by mobilities ranging from $M_{F} \approx 44$ to $M_{F} \approx 46$ and $\mathrm{pI}$ from 5.3 and 5.5 and encompassed five variants. The number of electromorphs detected by the 2-DEP analysis was at least two-fold higher than that obtained when $\mathrm{M}_{\mathrm{F}}$ and $\mathrm{pI}$ were considered separately.

Titration curves. Crude bacterial extracts were submitted to electrophoresis perpendicularly to a preformed stable carrier ampholyte $\mathrm{pH}$ gradient in order to obtain mobility curves which were revealed by specific staining. Electromorphs $2\left(\mathrm{pI} 5 \cdot 125, \mathrm{M}_{\mathrm{F}} \approx 46\right)$ and $5\left(\mathrm{pI} 5, \mathrm{M}_{\mathrm{F}} \approx 52\right.$ ) (fig. 2) gave a titration pattern in which titration curves were indistinguishable in the acidic part of the gradient but separated in the basic part. This pattern is suggestive of a single substitution where a neutral amino acid in the former electromorph is replaced by an acidic amino acid in the latter. ${ }^{4}$ Results were similar with variants 2 and 4, 4 and 6, 3 and 4 , and 2 and 3 , suggesting the same type of aminoacid substitution between these various electromorphs.

When electromorphs $4\left(\mathrm{pI} 5, \mathrm{M}_{\mathrm{F}} \approx 51\right)$ and 8 (pI 5.15, $\mathbf{M}_{\mathrm{F}} \approx 51$ ) were titrated together. the pattern was suggestive of single substitution of a neutral amino acid in variant 5 by a basic amino acid in variant $9 .{ }^{4}$ Titration curves of variant $1\left(\mathrm{pI} 5 \cdot 5, \mathrm{M}_{\mathrm{F}} \approx 44\right.$, group 1) with variant 2 (group 2) could not be interpreted in

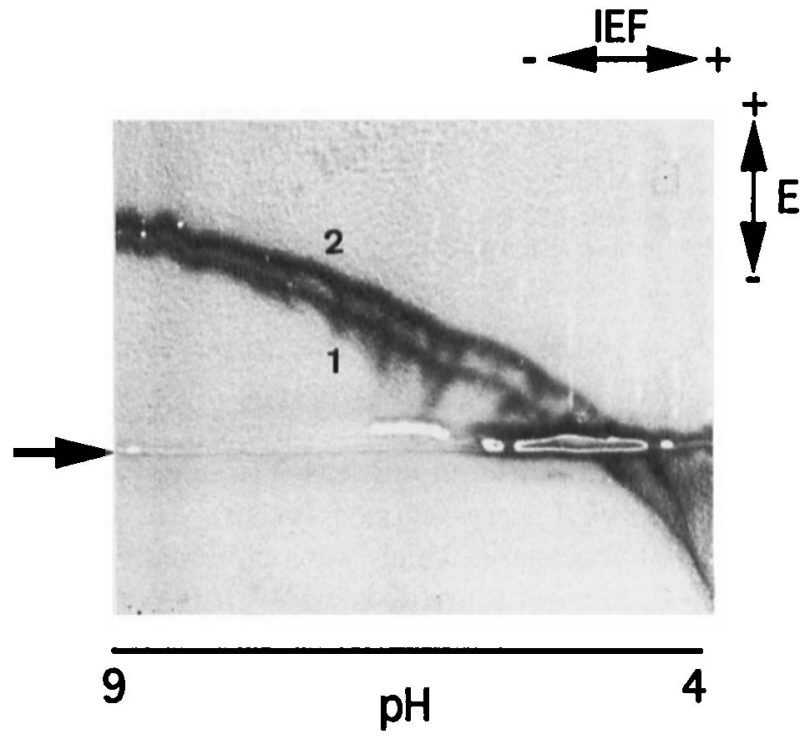

Fig. 2. Comparative titration curves of 1 , electromorph $2 ; 2$, electromorph 6 of esterase $\mathrm{P}_{3}$; $\rightarrow$ indicates the groove in which the crude enzyme extracts were placed.

terms of simple substitution. However, the two curves exhibited patterns that could evoke gross molecular similarity between them.

\section{RFLP of rDNA regions}

RFLP of the rDNA regions was studied with a panel of 134 strains selected on the basis of the data 


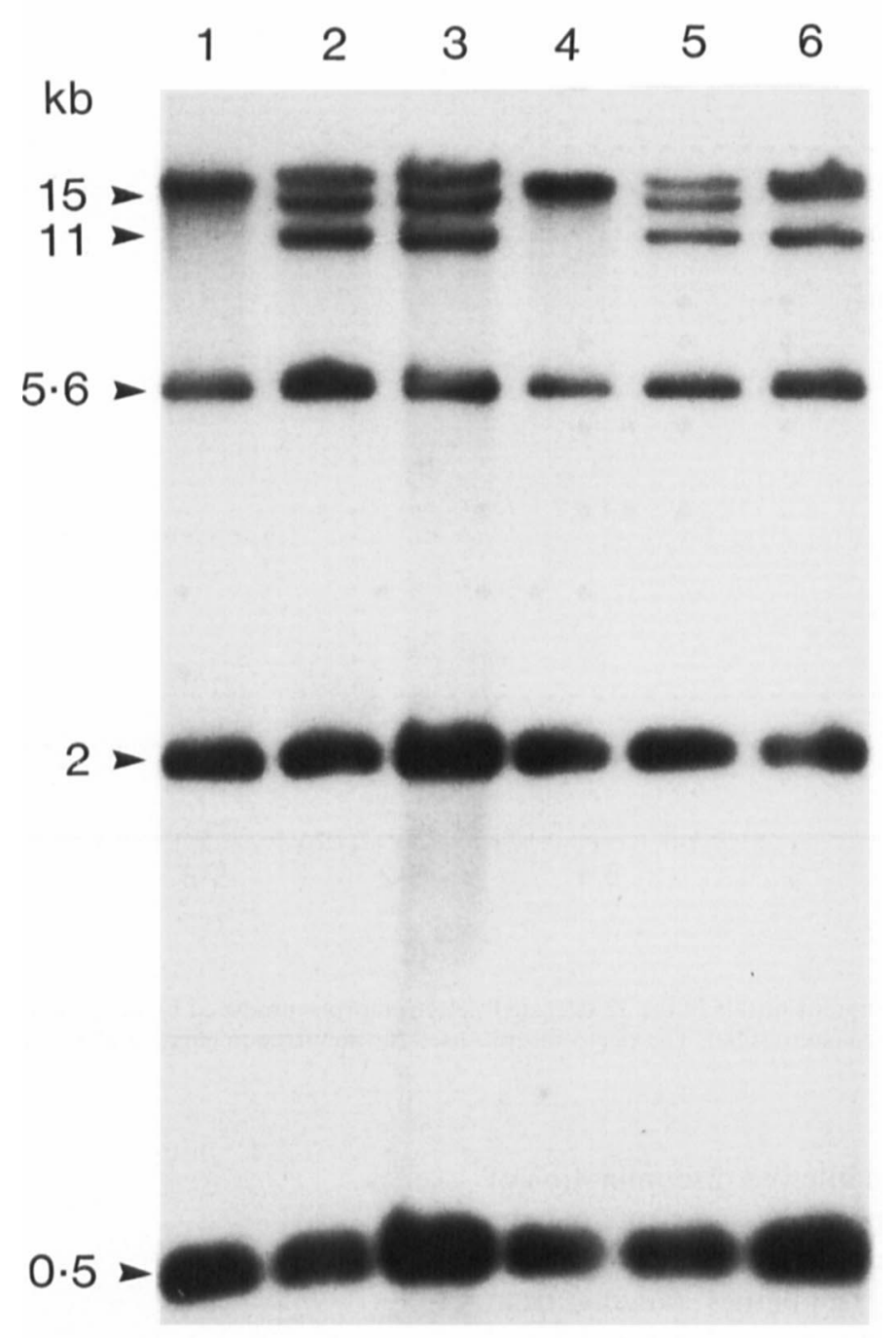

Fig. 3. A representative RFLP pattern of $P$. aeruginosa rDNA regions obtained by digestion with HindIIl enzyme. Lanes 1 and 4, pattern c; $\mathbf{2 , 3}$ and $\mathbf{5}$, pattern a; 6, pattern $d$.

obtained with the esterase electrophoretic typing, i.e., one or two strains of each zymotype plus 59 strains belonging to the most frequent zymotype 18. Among the six restriction endonucleases tested, HindIII, $E c o$ RI and $B c l l$ were retained for the size and the number of fragments which were obtained. HindIII digestion produced four-to-six rDNA fragments from 0.5 to $37 \mathrm{~kb}$ in size (fig. 3). Their combination allowed recognition of nine rDNA RFLP patterns within the $134 P$. aeruginosa strains (fig. 4A). EcoRI digestion produced two-to-four rDNA fragments ranging in size from 4.5 to $19 \mathrm{~kb}$. Their combination allowed recognition of 11 rDNA RFLP patterns (fig. 4B). BclI digestion gave four-to-five rDNA fragments from 1.4 to $20 \mathrm{~kb}$ in size. Their combination indicated nine rDNA RFP patterns (fig. 4C).

A combination of patterns resulting from two or three digestions was used to define a ribotype. Thus, 20-25 distinct ribotypes were obtained with the combinations of two endonucleases, and 33 ribotypes were differentiated with the combination of three endonucleases (table IV). Some ribotypes were isolated more frequently than others. The most common ones were ribotype $\mathrm{B}$ (found in 49 strains) and ribotype $\mathrm{D}$ (19 strains). Ribotypes A, C, E, G, I, L, M, N, P, S, T, $\mathrm{U}, \mathrm{V}, \mathrm{X}$ and $\mathrm{Y}$ encompassed two-to-six strains only. Sixteen ribotypes were represented by single isolates.

\section{Comparison of esterase electrophoretic typing, ribotyping and serotyping}

Esterase electrophoretic typing and serotyping did not appear to correlate, as within each of the serogroups, the strains exhibited various zymotypes, while several serogroups were found in each of the more frequently occurring zymotypes (table III). The same result was obtained when ribotyping and serotyping were compared. However, the strains of zymotypes 2-5 belonged to ribotype $P$ and serogroup 012 .

Combination of esterase typing and ribotyping allowed the delineation of 89 types among the 134 strains studied (table IV); each type was designated as the association of a given zymotype to a given ribotype. The most common type was type $29 / \mathrm{B}$, found in 34 strains. The type strain of the species, ATCC 10145 exhibited type 29/A, which was less frequent. The 

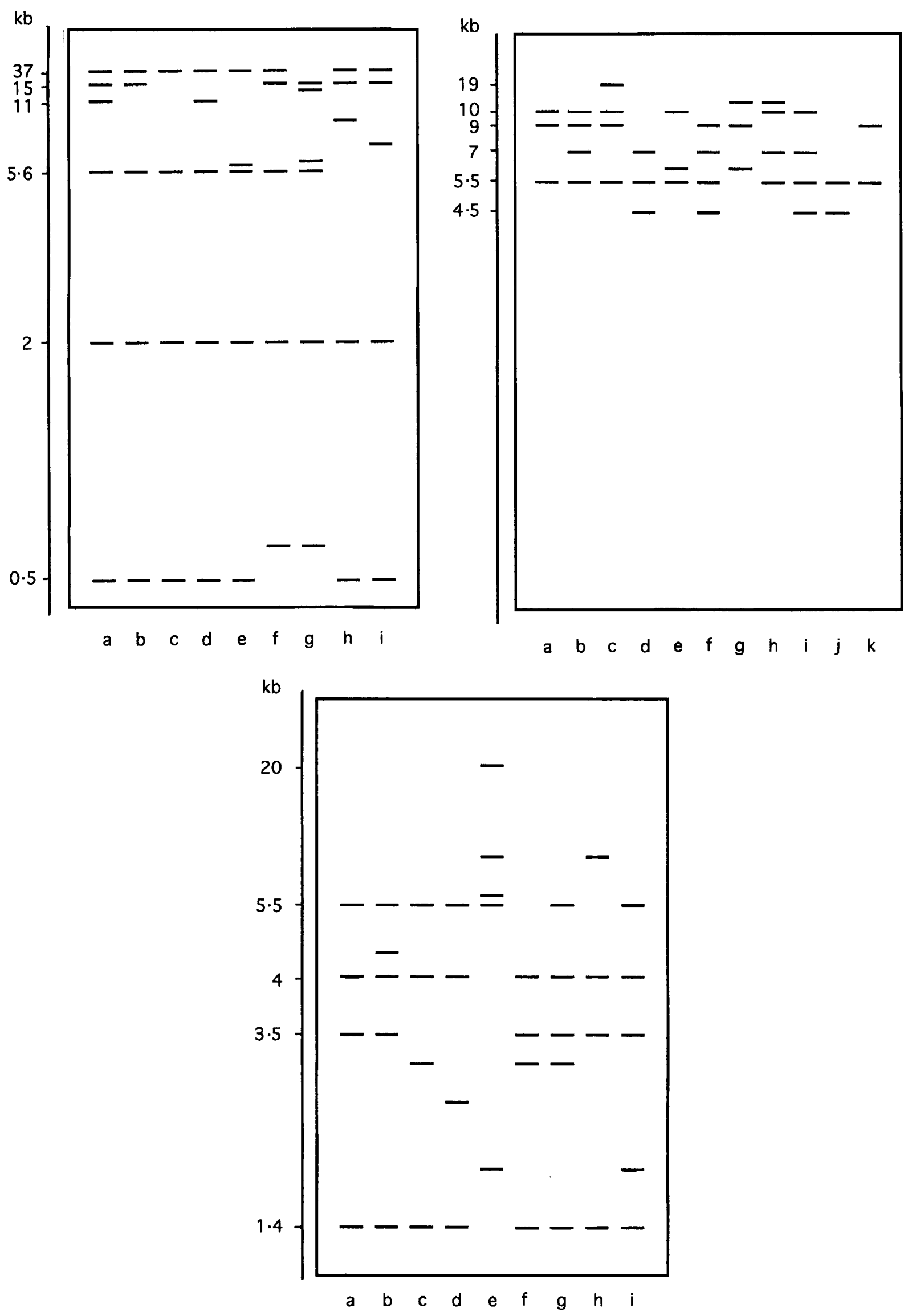

Fig. 4. RFLP rDNA patterns of $P$. aeruginosa strains: schematic representation of (A) HindIII restriction pattern, (B), EcoRI restriction pattern, (C), $B c I$ restriction pattern (numbered as in table IV) of DNA from strains after hybridising to ${ }^{32} \mathrm{P}-\mathrm{labelled} E$. coli $\mathrm{rDNA}$ probe. 
Table IV. Distribution of the $259 P$. aeruginosa strains studied among the 33 ribotypes resulting from the combination of the RFLP rDNA profiles obtained with $H i n d I I I, E c o$ RI and $B c l$ l enzymes: the zymotypes exhibited by the strains are indicated

\begin{tabular}{|c|c|c|c|c|c|}
\hline \multirow{2}{*}{ Ribotype } & \multicolumn{3}{|c|}{ rDNA RFLP pattern } & \multirow{2}{*}{ Zymotype } & \multirow{2}{*}{$\begin{array}{l}\text { Number of } \\
\text { strains }\end{array}$} \\
\hline & HindIII & Eco RI & $B c l I$ & & \\
\hline A & $\mathrm{a}$ & a & $\mathrm{a}$ & $29,37,65$ & 3 \\
\hline B & a & $\mathrm{b}$ & a & $\begin{array}{c}6,29,31-35,38,52 \\
55-58,60,62,67\end{array}$ & 49 \\
\hline $\mathrm{C}$ & $\mathrm{c}$ & b & c & 29 & 2 \\
\hline $\mathrm{D}$ & $\mathrm{b}$ & a & $\mathrm{a}$ & $\begin{array}{c}8,10,12,16,23,29 \\
39,40,44,46,47 \\
51,56,63\end{array}$ & 19 \\
\hline $\mathrm{E}$ & $\mathrm{b}$ & a & $\mathrm{b}$ & $17-19$ & 4 \\
\hline $\mathrm{F}$ & e & $\mathrm{b}$ & a & 9,29 & 1 \\
\hline G & c & c & $\mathbf{a}$ & $26,29,30$ & 4 \\
\hline $\mathrm{H}$ & a & $\mathrm{b}$ & f & 29 & 1 \\
\hline I & d & b & $\mathbf{a}$ & $21,29,48,53,61$ & 6 \\
\hline $\mathrm{J}$ & d & d & a & 27 & 1 \\
\hline $\mathrm{K}$ & $\mathrm{f}$ & $\mathrm{e}$ & a & 22 & 1 \\
\hline $\mathrm{L}$ & $\mathrm{b}$ & b & $\mathrm{a}$ & $1,7,14,15,29$ & 6 \\
\hline $\mathrm{M}$ & d & $\mathrm{b}$ & b & $24,25,34$ & 3 \\
\hline $\mathrm{N}$ & d & $\mathrm{b}$ & e & 28,29 & 2 \\
\hline $\mathrm{O}$ & c & $\mathrm{a}$ & d & 51 & 1 \\
\hline$P$ & g & $\mathrm{g}$ & $\mathrm{a}$ & $2-5$ & 4 \\
\hline Q & $\mathrm{c}$ & $\mathrm{a}$ & a & 20 & 1 \\
\hline $\mathrm{R}$ & $\mathrm{a}$ & $\mathrm{b}$ & b & 29 & 1 \\
\hline $\mathrm{s}$ & $\mathrm{h}$ & $\mathrm{b}$ & a & 29 & 2 \\
\hline $\mathrm{T}$ & d & a & a & $29,31,43$ & 3 \\
\hline $\mathrm{U}$ & $\mathrm{a}$ & c & a & 36,50 & 2 \\
\hline $\mathrm{V}$ & $\mathrm{b}$ & $\mathrm{c}$ & $\mathrm{a}$ & 29,45 & 4 \\
\hline W & $\mathrm{c}$ & $\mathrm{h}$ & $\mathrm{h}$ & 49 & 1 \\
\hline $\mathrm{X}$ & $\mathrm{c}$ & $\mathrm{f}$ & $\mathrm{a}$ & 29,$54 ; 56$ & 3 \\
\hline $\mathrm{Y}$ & $\mathbf{a}$ & $\mathrm{b}$ & $\mathrm{g}$ & 59,61 & 2 \\
\hline $\mathrm{Z}$ & b & $\mathbf{a}$ & $\mathrm{h}$ & 64 & 1 \\
\hline AA & $\mathrm{b}$ & f & $\mathrm{i}$ & 29 & 1 \\
\hline $\mathrm{AB}$ & d & $\mathrm{b}$ & c & 29 & 1 \\
\hline $\mathrm{AC}$ & d & $\mathrm{i}$ & $\mathrm{b}$ & 29 & 1 \\
\hline $\mathrm{AD}$ & $\mathrm{i}$ & b & $\mathrm{a}$ & 30 & 1 \\
\hline $\mathrm{AE}$ & $\mathrm{b}$ & $\mathrm{j}$ & $\mathrm{b}$ & 13 & 1 \\
\hline $\mathrm{AF}$ & $\mathrm{b}$ & $\mathrm{k}$ & a & 11 & 1 \\
\hline $\mathrm{AG}$ & d & c & $\mathrm{a}$ & 41 & 1 \\
\hline
\end{tabular}

The rDNA RFLP patterns are designated as in fig. 4.

distribution of the strains was identical among $\mathrm{CF}$ and non-CF patients.

\section{Discussion}

PAGE and IEF were complementary in their resolution of enzyme polymorphism and refined intraspecies molecular relationships of $P$. aeruginosa. Indeed, the numbers of esterase $\mathrm{P}_{3}$ variants detected by PAGE, IEF and on the 2-DEP were 8, 13 and 32, respectively. Results of this type have been observed previously for several bacterialenzymes ${ }^{3,4}$ While analysis of the genetic structure of a bacterial population is generally based on the number of electrophoretically detected variants, ${ }^{2,25-27}$ the conjunction of findings obtained by 2-DEP and titration curves constitutes a novel approach to our understanding of the molecular relatedness of the various allozymes. ${ }^{6}$ For instance, the esterase $P_{3}$ variants belonging to groups 1 and 2 in fig. 1 were distantly related to each other in molecular terms as demonstrated by their titration curves, indicating a phylogenetic divergence between these variants. In contrast, variants of group 1 appeared to be closely related. Similar conclusions were reached from the analysis of carboxylesterase B of $E$. $\operatorname{coli}^{6}$ and esterase $\beta$ a of Providencia alcalifiaciens $^{5}$. Interestingly, variants of group 2 were detected in a group of $P$. aeruginosa strains belonging to serogroup $\mathrm{O} 12^{28,29}$ and originating from a single hospital. This divergence was confirmed by both esterase typing and ribotyping. Indeed, these strains exhibited specific zymotypes 2-5 and a distinct ribotype $\mathbf{P}$ corresponding to two very different rDNA RFLP patterns after EcoRI and HindIII digestions (table IV, fig. 4). Consequently, they could constitute a distinct group within the species. The level of intra-species molecular relatedness evaluated for esterase $\mathrm{P}_{3}$ in terms of amino-acid substitution correlates with the divergence between the strains observed at the genotype level by ribotyping.

Electrophoretic typing of esterases within $P$. aeruginosa species represents a potential method for epidemiological analysis ${ }^{14,15}$ as 67 zymotypes were detected 
among the 259 strains studied. This method is simple and rapid and might be used more extensively to type epidemiologically related strains, as for other nosocomial pathogens. ${ }^{30,31}$ The absence of correlation between zymotyping and ribotyping enhanced the discriminative power of each individual method in differentiating 89 types among the strains and indicates that the two methods could be used advantageously in parallel in a combined typing system-as was suggested previously. ${ }^{32}$ On the other hand, this system could be considered as a screening method before DNA-DNA hybridisation studies. The reference strain of the species, ATCC 10145, exhibited type 29/A, which was an infrequent type, while the 34 strains belonging to type 29/B appeared to be more representative of $P$. aeruginosa. Comparable results were previously obtained with the genus Acinetobacter. ${ }^{1}$

Six endonucleases were tested in the study of rDNA RFLP. The HaeIII digestion pattern visualised with ethidium bromide was composed of low molecular size fragments. This result is explained by the site of restriction of HaeIII (GGCC), a four base pair cutter, and the $\mathrm{G}+\mathrm{C}$ mol $\%$ of $P$. aeruginosa $(67 \%)$ which is higher than that of many other bacteria (e.g., E. coli $50 \%$; Staphylococcus aureus $34 \%$ ). This illustrates the fact that before ribotyping, the restriction enzyme must be chosen from the GC mol \% data. The number of ribotypes resulting from the use of three endonucleases ${ }^{33}$ was higher than that obtained with two endonucleases (20-25). This fact indicates that several endonucleases must be used to enhance the discrimin- ative power of ribotyping, as was demonstrated previously for the genera Branhamella ${ }^{34}$ and Yersinia. ${ }^{13}$ On the other hand, some strains were found to be atypical with one endonuclease only, indicating that the genotypic diversity of $P$. aeruginosa species must be measured by the comparison of data obtained by several restriction enzymes.

The absence of correlation demonstrated between serotyping, esterase typing and ribotyping argues for a high level of heterogeneity within the species unlike $E$. coli, where relationships within bacterial clones were established by the same techniques. ${ }^{11}$ Ribotyping and esterase typing appeared to be more discriminative than serotyping, as 33 and 67 types, respectively, were determined with the first two techniques and 16 with the third. On the other hand, O serotyping is of limited value for epidemiological studies of $P$. aeruginosa infection in CF patients, as many strains are either polyagglutinable, autoagglutinable or nontypable. ${ }^{15,33,35}$ The variation of serotype in strains exhibiting identical esterase type and ribotype could represent a subtle genetic change within these strains, such as phage conversion, gene duplication or phase variation. ${ }^{36}$ Consequently, the use of molecular typing methods such as esterase typing, ribotyping, genome fingerprinting by field inversion gel electrophoresis ${ }^{35}$ and RFLP in the exotoxin $\mathrm{A}^{36}$ or pili gene regions ${ }^{33,37}$ appear to be more advantageous than the phenotypic systems for $P$. aeruginosa strain differentiation.

The authors thank Madame C. Gaillard, Madame N. Hautier and Madame M. Labrousse for technical assistance.

\section{References}

1. Picard B, Goullet P, Bouvet PJM, Decoux G, Denis JB. Characterization of bacterial genospecies by computerassisted statistical analysis of enzyme electrophoretic data. Electrophoresis 1989; 10: 680-685.

2. Selander RK, Caugant DA, Ochman H, Musser JM, Gilmour MN, Whittam TS. Methods of multilocus enzyme electrophoresis for bacterial population genetics and systematics. Appl Environ Microbiol 1986; 51: 873-884.

3. Goullet P, Picard B. A two-dimensional electrophoretic profile for bacterial esterases. Electrophoresis 1985; 6: 132-135.

4. Righetti PG, Krishnamoorthy R, Gianazza E, Labie D. Protein titration curves by combined isoelectric focusingelectrophoresis with hemoglobin mutants as models. $J$ Chromatogr 1978; 166: 455-460.

5. Goullet P, Picard B, Krishnamoorthy R. An evaluation of allozyme amino acid substitutions for the study of molecular relationships in Providencia strains. Ann Inst Pasteur/Microbiol 1988; 139: 689-702.

6. Picard B, Goullet P, Krishnamoorthy R. A novel approach to study of the structural basis of enzyme polymorphism. Analysis of carboxylesterase B of Escherichia coli as model. Biochem $J$ 1987; 241 : 877-881.

7. Nei M, Li W-H. Mathematical model for studying genetic variation in terms of restriction endonucleases. Proc Natl Acad Sci USA 1979; 76: 5269-5273.

8. Grimont F, Grimont PAD. Ribosomal ribonucleic acid gene restriction patterns as potential taxonomic tools. Ann Inst Pasteur/Microbiol 1986; 137B: 165-175.

9. Picard-Pasquier N, Ouagued M, Picard B, Goullet P, Krishnamoorthy R. A simple, sensitive method of analyzing bacterial ribosomal DNA polymorphism. Electrophoresis $1989 ; 10$ : 186-189.

10. Stull TL, LiPuma JJ, Edlind TD. A broad-spectrum probe for molecular epidemiology of bacteria: ribosomal RNA. $J$ Infect Dis 1988; 157: 280-286.

11. Arthur M, Arbeit RD, Kim C et al. Restriction fragment length polymorphisms among uropathogenic Escherichia coli isolates: pap-related sequences compared with $r r n$ operons. Infect Immun 1990; 58: 471-479.

12. Denny TP, Gilmour MN, Selander RK. Genetic diversity and relationships of two pathovars of Pseudomonas syringae. $J$ Gen Microbiol 1988; 134: 1949-1960.

13. Picard-Pasquier N, Picard B, Heeralal S, Krishnamoorthy R, Goullet P. Correlation between ribosomal DNA polymorphism and electrophoretic enzyme polymorphism in Yersinia. J Gen Microbiol 1990; 136: 1655-1666.

14. Goullet P, Picard B. Pseudomonas aeruginosa isolate typing by esterase electrophoresis. FEMS Microbiol Lett 1991; 78: 195-200.

15. Denamur E, Picard B, Goullet P, Bingen E, Lambert N, Elion J. Complexity of Pseudomonas aeruginosa infection in cystic fibrosis: combined results from esterase electrophoresis and rDNA restriction fragment length polymorphism analysis. Epidemiol Infect 1991; 106: 531-539.

16. Liu PV, Matsumoto H, Kusama H, Bergan T. Survey of heatstable, major somatic antigens of Pseudomonas aeruginosa. Int J Syst Bacteriol 1983; 33: 256-264.

17. Lennox ES. Transduction of linked genetic characters of the host by bacteriophage P1. Virology 1955; 1: 190-206.

18. Goullet P. An esterase zymogram of Escherichia coli. J Gen Microbiol 1973; 77: 27-35.

19. Uriel J. Méthode d'électrophorèse dans des gels d'acrylamideagarose. Bull Soc Chim Biol 1966; 48: 969-982.

20. Vesterberg $\mathbf{O}$, Svensson $H$. Isoelectric fractionation analysis and characterization of ampholytes in natural $\mathrm{pH}$ gradients. IV. Further studies on the resolving power in 
connection with separation of myoglobins. Acta Chem Scand 1966; 20: 820-834.

21. Lawrence SH, Melnick PJ, Weimer HE. A species comparison of serum proteins and enzymes by starch gel electrophoresis. Proc Soc Exp Biol Med 1960; 105: 572-575.

22. Uriel J. Caractérisation des cholinestérases et d'autres estérases carboxyliques après électrophorèse et immunoélectrophorèse en gélose. 1. application à l'étude des estérases du sérum humain normal. Ann Inst Pasteur 1961; 101: 104-119.

23. Southern EM. Detection of specific sequences among DNA fragments separated by gel electrophoresis. $J$ Mol Biol 1975; 98: 503-517.

24. Nei M. Estimation of average heterozygosity and genetic distance from a small number of individuals. Genetics 1978; 89: 583-590.

25. Ochman H, Whittam TS, Caugant DA, Selander RK. Enzyme polymorphism and genetic population structure in Escherichia coli and Shigella. J Gen Microbiol 1983; 129: 2715-2726.

26. Selander RK. Protein polymorphism and the genetic structure of natural populations of bacteria. In: Ohta T, Aoki K (eds) Population genetics and molecular evolution. Berlin, Springer-Verlag. 1985: 85-106.

27. Selander RK, Caugant DA, Whittam TS. Genetic structure and variation in natural populations of Escherichia coli. In: Ingraham JL et al. (eds) Escherichia coli and Salmonella typhimurium, cellular and molecular biology. Washington, D.C., American Society for Microbiology. 1987: $1625-1648$

28. Pitt TL. Epidemiological typing of Pseudomonas aeruginosa. Eur J Clin Microbiol Infect Dis 1988; 7 : 238-247.
29. Pitt TL, Livermore DM, Pitcher D, Vatopoulos AC, Legakis NJ. Multiresistant serotype O12 Pseudomonas aeruginosa: evidence for a common strain in Europe. Epidemiol Infect 1989; 103: 565-576

30. Picard B, Goullet P. Epidemiological complexity of hospital Aeromonas infections revealed by electrophoretic typing of esterases. Epidemiol Infect 1987; 98: 5-14.

31. Picard B, Bruneau B, Goullet P. Demonstration of an outbreak of Serratia marcescens infections in a medical intensive care unit by esterase electrophoretic typing. J Hosp Infect 1988; 11: 194-195.

32. Griffith SJ, Nathan C, Selander RK et al. The epidemiology of Pseudomonas aeruginosa in oncology patients in a general hospital. J Infect Dis 1989; 160: 1030-1036.

33. Speert DP, Campbell ME, Farmer SW, Volpel K, Joffe AM, Paranchych W. Use of a pilin gene probe to study molecular epidemiology of Pseudomonas aeruginosa. J Clin Microbiol 1989; 27 : 2589-2593.

34. Denamur E, Picard-Pasquier N, Mura C, Picard B, Orfila J, Krishnamoorthy $\mathbf{R}$. Comparison of molecular epidemiological tools for Branhamella catarrhalis typing. Res Microbiol 1991; 142: 585-589.

35. Grothues D, Koopmann U, Von Der Hardt H, Tümmler B. Genome fingerprinting of Pseudomonas aeruginosa indicates colonization of cystic fibrosis siblings with closely related strains. J Clin Microbiol 1988; 26: 1973-1977.

36. Ogle JW, Janda JM, Woods DE, Vasil ML. Characterization and use of a DNA probe as an epidemiological marker for Pseudomonas aeruginosa. J Infect Dis 1987; 155: 119-126.

37. Pasloske BL, Joffe AM, Sun $\mathrm{Q}$ et al. Serial isolates of Pseudomonas aeruginosa from a cystic fibrosis patient have identical pilin sequences. Infect Immun 1988; 56: 665-672. 